\title{
Regulations of the International Laser License System (ILLiS)
}

\author{
Section 1 \\ GENERAL
}

\begin{abstract}
Article 1: Purpose of the System
The purpose of the system is to offer an internationally-recognized licensure for all professionals working in any aspect of the field of medical laser.
\end{abstract}

\begin{abstract}
Article 2: System Governance
The system shall be under the governance of the NPO World Federation of Societies for Laser Medicine and Surgery (NPO WFSLMS), the WFSLMS and the International Society for Laser Surgery and Medicine (ISLSM), under the auspices of the International Academy Laser Medicine and Surgery (IALMS). Control of the system shall be administered from the NPO WFSLMS Business Center, located at the offices of the Japan Medical Laser Laboratory.
\end{abstract}

\section{Article 3: Qualifications}

There shall be two types of qualification, namely the individual qualification for individual professionals, and the institutional qualification for participating institutions.

\section{Article 4: Committees}

The system shall be under the control of two types of committee, namely the International Laser License Committee (ILLiC) and the International Laser Safety and Education Committee (ILaSEC).

\section{Article 5: The International Laser Specialist}

There shall be six types of specialist, namely the International Medical Laser Specialist (IMeLaS), the International Dental Laser Specialist (IDeLaS), the International Veterinary Laser Specialist (IVeLaS), the International Laser Nursing Specialist (ILNuS), the International Laser Engineering Specialist (ILES), and Physicist International Laser Specialist (P-ILaS).

\section{Section 2 \\ THE INTERNATIONAL LASER LICENCE COMMITTEE (ILLIC)}

There shall be two types of the subcommittee of the ILLiC, namely the Individual ILLiC and Institutional ILLiC.

The ILLiC shall be subdivided into the International Medical Laser License Committee (IMeLLiC), the International Dental Laser License Committee (IDeLLiC), the International Veterinary Laser License Committee (IVeLLiC), the International Laser Nursing License Committee (ILNuLiC) and the International Laser Engineering License Committee (ILELiC).

\section{Section 3 \\ THE INTERNATIONAL LASER SAFETY AND EDUCATION COMMITTEE (ILASEC)}

\section{Article 1: The Remit of the ILaSEC}

The remit of the ILaSEC shall be to oversee the organization and execution of the didactic and practical sections which form part of the overall ILLiS training, and the subsequent examination.

\section{Article 2: The Didactic Section}

The didactic section shall be designed in such a way as to give candidates a thorough grounding in the relevant photobiological basics, to enable an understanding of light-tissue interaction, and to grasp how to manipulate parameters to achieve specific photoeffects. In addition, theoretical and practical aspects of safety with all light sources used in medicine and surgery shall be taught, with specific attention to the treatment room and research laboratory where applicable. The responsibility of the ILaSEC shall include selection of the lecturers and verification of the adequate standard of the didactic lectures.

\section{Article 3: The Practical Section}

The practical section shall incorporate familiarization with the setting up of a variety of photosurgical and phototherapeutic systems; practical safety aspects of each individual system; and hands-on familiarization with manipulation and control of system parameters to achieve the desired range of tissue photoeffects. 


\section{Article 4: The Examination}

On completion of the course, candidates shall sit a written examination, consisting of a series of multiple choice questions based on the contents of the didactic and hands-on sections. Candidates are required to pass the examination in order to be considered for ILLiS certification. In the case of a fail mark, candidates shall be required to retake the entire course and resit the examination.

\section{Article 5: Exceptions}

Note that any ILLiS candidates who have already taken the laser safety examination approved in their country, and passed, need not take either the ILLiS hands-on course or the written examination, but must attend the didactic sessions. If candidates already hold both a Medical Doctor's/Dentist's/ Veterinarian's/Nurse's/Engineer's License from their own country or state and a corresponding national or international Laser Specialist License, attendance at the examination and the hands-on training will be waived, but candidates must still attend the didactic sessions. In this case, the submission of certified copies of each license is required when registering for the ILLiS course.

\section{Section 4 \\ INDIVIDUAL ILLiS CERTIFICATION}

\section{Article 1: Grades of Certification}

Individual ILLiS Certification shall be offered under the following grades for International Medical Laser Specialists (IMeLaS), International Dental Laser Specialists (IDeLaS), International Veterinary Laser Specialists (IVeLaS). (In ascending order), C-, B-, A-, and I-: ('I' denotes 'Instructor') Only one grade can be held at any given time. Candidates for the Instructor grade in each field and for P-ILaS can be recommended by the Executive Committee of NPO WFSLMS, WFSLMS and ISLSM. International Laser Nursing Specialists (ILNuS), International Laser Engineer Specialists (ILES) and Physicist International Laser Specialists (P-ILaS) shall have no grading system. In addition, any individual ILLiS certificate holder who dies while holding valid certification shall be indicated by the suffix (D) after their particular certification.

\section{Article 2: Honorary Certification}

Any outstanding contributor to the field shall be offered honorary certification in their specific area of expertise as in Section 4 Article 1 above. In the case of IMeLaS certification, Hon-IMeLaS shall be offered to the past president of any recognized international medical laser congress.

\section{Article 3: P-ILaS}

Physicist International Laser Specialists (P-ILaS) shall be entitled to teach any of the didactic courses for ILLiS certification.

\section{Article 4: Mandatory Qualifications and Requirements}

The necessary qualifications and requirements in the case of candidates for Individual ILLiS Certification are as set out in the following table.

Table a: ILLiS certification requirements

\begin{tabular}{|c|c|c|c|c|c|c|c|}
\hline \multirow{2}{*}{ Item } & \multicolumn{4}{|c|}{ Crade } & \multirow{2}{*}{ ILNuS } & \multirow{2}{*}{ ILES } & \multirow{2}{*}{ P-lLaS } \\
\hline & $\mathrm{C}$ & B & A & I & & & \\
\hline Application form ${ }^{1}$ & $\mathrm{O}$ & $\mathrm{O}$ & $\mathrm{O}$ & $\mathrm{O}$ & $\mathrm{O}$ & $\mathrm{O}$ & $\mathrm{O}$ \\
\hline Licence to Practice & $\mathrm{O}$ & $\mathrm{O}$ & $\mathrm{O}$ & $\mathrm{O}$ & $\mathrm{O}$ & $\mathrm{O}$ & $\mathrm{O}$ \\
\hline Achievement & $\mathrm{O}$ & $\mathrm{O}$ & $\mathrm{O}$ & $\mathrm{O}$ & $\mathrm{O}$ & $\mathrm{O}$ & $\mathrm{O}$ \\
\hline Specialty certification & $\mathrm{O}$ & $\mathrm{O}$ & $\mathrm{O}$ & $\mathrm{O}$ & optional & optional & optional \\
\hline Examination diploma ${ }^{2}$ & $\mathrm{O}$ & $\mathrm{O}$ & $\mathrm{O}$ & $\mathrm{O}$ & $\mathrm{O}$ & $\mathrm{O}$ & $\mathrm{O}$ \\
\hline Institutional certification ${ }^{3}$ & $\mathrm{O}$ & $\mathrm{O}$ & $\mathrm{O}$ & $\mathrm{O}$ & $\mathrm{O}$ & $\mathrm{O}$ & $\mathrm{O}$ \\
\hline International laser congresses attended ${ }^{4}$ & 1 & 2 & 3 & 5 & 1 & 1 & 5 \\
\hline ISLSM Membership 5 & 0 yr(join) & 3 & 7 & 10 & 0 yr(join) & 0 yr(join) & 10 \\
\hline
\end{tabular}

1: The application form can be downloaded from the APALMS website: http://www.apalms2012.tw/ILLiS.html and sent by email or fax to ILLiS Secretariat: wfslms@jmll.co.jp / +81-3-5269-1410

2: The ILLiS examination diploma is not required for candidates who have already passed their national equivalent certification. However, they must attend the didactic course, but need not attend the hands-on session or the written examination.

3: Written certification from institute director or equivalent

4: Certificates of Attendance required

5: Alternatively, ISLSM Life Membership is acceptable in all cases 
Table b: Table of achievements in laser application

\begin{tabular}{|c|c|c|c|c|c|c|c|}
\hline \multirow{2}{*}{ Item } & \multicolumn{4}{|c|}{ Grade } & \multirow{2}{*}{ ILNuS } & \multirow{2}{*}{ ILES } & \multirow{2}{*}{ P-ILaS } \\
\hline & $\mathrm{C}$ & B & $\mathrm{A}$ & I & & & \\
\hline Years of laser experience & 0 & 3 & 7 & 10 & 2 & 0 & 10 \\
\hline Case reports & 0 & 0 & 10 & 10 & 0 & 0 & 0 \\
\hline Minimum acquired points* & 40 & 80 & 200 & 250 & 20 & 20 & 250 \\
\hline
\end{tabular}

*Please calculate total points from the following tables. Please use the sum of all points acquired in all tables. Note that for Grades A and I, candidates must have published at least 2 case reports in a peer-reviewed international journal.

Table c: Congress Attendance Points

\begin{tabular}{|c|c|c|c|c|}
\hline \multirow[b]{2}{*}{ Congresses attended } & \multirow[b]{2}{*}{$\begin{array}{c}\text { Congress } \\
\text { Attendances }\end{array}$} & \multicolumn{3}{|c|}{ Presentations } \\
\hline & & $\begin{array}{l}\text { Symposium/ } \\
\text { Workshop etc. }\end{array}$ & $\underset{\left(1^{\text {st }} \text { speaker }\right)}{\text { Normal }}$ & $\begin{array}{l}\text { Normal presentation } * \\
\left(2^{\text {nd }} \text { or other speaker }\right)\end{array}$ \\
\hline ISLSM & 20 & 25 & 15 & 7 \\
\hline WFSLMS & 20 & 25 & 15 & 7 \\
\hline WALT & 20 & 25 & 15 & 7 \\
\hline IPTA & 20 & 25 & 15 & 7 \\
\hline IPA & 20 & 25 & 15 & 7 \\
\hline APALMS & 20 & 25 & 15 & 7 \\
\hline ELA & 20 & 25 & 15 & 7 \\
\hline ESLAS & 20 & 25 & 15 & 7 \\
\hline Laser Florence & 20 & 25 & 15 & 7 \\
\hline IALSM & 20 & 25 & 15 & 7 \\
\hline $\begin{array}{l}\text { Didactic and hands-on courses } \\
\text { for ILLiS certification }\end{array}$ & 40 & 25 & - & - \\
\hline $\begin{array}{l}\text { Any other laser-related international congress, } \\
\text { symposium, etc. (medical, dental, etc.) }\end{array}$ & 15 & 20 & 10 & 5 \\
\hline
\end{tabular}

WALT, World Association for Laser Therapy; IPTA, International Phototherapy Association; IPA, International Photodynamic Therapy Association; APALMS, Asian-Pacific Association for Laser Medicine and Surgery; ELA, European Laser Association; ESLAS, European Society for Laser Aesthetic Surgery; IALSM, International Association for Laser and Sports Medicine.

* Includes industrial/commercial presentations

Table d: Written work

\begin{tabular}{|l|c|c|c|c|c|c|c|c|c|c|}
\hline \multicolumn{1}{|c|}{ Type of Writing } & \multicolumn{4}{|c|}{ Author } & \multicolumn{5}{c|}{ Coauthor } \\
\cline { 2 - 12 } & RP & OP & CR & BC & LE & RP & OP & CR & BC & LE \\
\hline $\begin{array}{l}\text { Laser Therapy (and any other major } \\
\text { international peer-reviewed journal) }\end{array}$ & 80 & 70 & 60 & 50 & 40 & 40 & 35 & 30 & 25 & 20 \\
$\begin{array}{l}\text { Book chapter } \\
\text { Whole book }\end{array}$ & 80 & - & - & - & - & 40 & - & - & - & - \\
\hline
\end{tabular}

RP, Review paper; OP, Original paper; CR, Case report; BC, Brief communication; LE, Letter to the Editor

\section{Article 5: Upgrade Policy}

Upgrading from an existing grade to a higher grade will be possible once the appropriate criteria have been fulfilled, including the length of active ISLSM Membership. It will be possible to apply for initial certification at any grade from the 2nd to the 4th grades (A-IMeLaS - C-IMeLaS), but applicants for 1st Grade certification (I-IMeLaS) must first hold an A-IMeLaS (2nd Grade) certification. Notwithstanding the above, if a candidate joins the ISLSM as a Life Member, then the length of ISLSM membership criterion will be deemed to have been satisfied for all grades of IMeLaS certification.

\section{Article 6: Certification Renewal}

ILLiS certificate holders are required to renew their certification every 5 years until the age of 65, after which renewal is not required. To renew, candidates must satisfy all requirements for their grade as per Table b above, and in addition must attend the full educational and practical courses, but will not be required to sit the examination. 